\title{
Comparative Studies on Flotation Performance of Saturated Fatty Acids and Unsaturated Fatty Acids Separated from Hogwash Oil
}

\author{
Wenda Guo, Yujie Cai * ${ }^{\mathbb{D}}$, Yimin Zhu, Yanjun Li and Yongsheng Sun
}

check for updates

Citation: Guo, W.; Cai, Y.; Zhu, Y.; Li, Y.; Sun, Y. Comparative Studies on Flotation Performance of Saturated Fatty Acids and Unsaturated Fatty Acids Separated from Hogwash Oil. Minerals 2021, 11, 50. https:// doi.org/10.3390/min11010050

Received: 10 December 2020 Accepted: 3 January 2021 Published: 6 January 2021

Publisher's Note: MDPI stays neutral with regard to jurisdictional clai$\mathrm{ms}$ in published maps and institutional affiliations.

Copyright: (C) 2021 by the authors. Licensee MDPI, Basel, Switzerland. This article is an open access article distributed under the terms and conditions of the Creative Commons Attribution (CC BY) license (https:// creativecommons.org/licenses/by/ $4.0 /)$.
School of Resource and Civil Engineering, Northeastern University, Shenyang 110819, China; gedaya123@163.com (W.G.); zhuyimin@mail.neu.edu.cn (Y.Z.); liyanjun@mail.neu.edu.cn (Y.L.); yongshengsun@mail.neu.edu.cn (Y.S.)

* Correspondence: cyj301235@163.com

\begin{abstract}
Low flotation recovery, high pulp temperature, and large dosage of reagents are the typical disadvantages when using mixed fatty acids (MFA) prepared from hogwash oil for flotation directly. To determine the type of fatty acid that yields poor flotation performance, flotation performance and adsorption characteristics of saturated fatty acids (SFA) and unsaturated fatty acids (UFA) separated from the MFA were studied in our work. GC-MS, FT-IR, iodine value detection and melting point measurement showed that UFA contained $-\left(\mathrm{CH}=\mathrm{CH}-\mathrm{CH}_{2}\right)_{\mathrm{n}}$ - groups and had much lower melting point. Quartz flotation tests were used to compare the flotation performance of UFA and SFA, which showed that UFA had excellent low-temperature floatability, and the flotation recovery of UFA was 35 percentage points higher than that of SFA at $20^{\circ} \mathrm{C}$ and $\mathrm{pH}=11.5$. Zeta potential, FT-IR and XPS analysis indicated that UFA and SFA could adsorb onto the surface of activated quartz through chemisorption and hydrogen bonding. However, the adsorption of UFA was much stronger and more favorable; thus, the reason MFA have poor flotation performance was the presence of SFA.
\end{abstract}

Keywords: hogwash oil; fatty acids; separation; quartz flotation; adsorption mechanism

\section{Introduction}

Quartz is a type of widely distributed minerals on the surface of the earth, mainly existing in the forms of crystal, quartzite, quartz sandstone, vein quartz, and so on. In addition, it is one of the most common gangue minerals, associated with oxides, sulfides, silicates, and phosphates [1]. Direct flotation with cationic amine collectors is a typical method to select quartz. Another typical method is activated by the polyvalent metal ions, and then using anionic collectors for flotation [2]. The most extensively used anionic collectors are long carbon chain length fatty acids and their salts [3]. For example, RA series collectors (RA-315, RA-515, RA-715, and RA-915) [4,5] are fatty acids collectors which have been proved to be efficient, economical, and nontoxic, and have been widely used in quartz flotation in China.

According to estimates, there are approximately 8 to 15 million tons of hogwash oil annually produced from the catering industry in China [6]. Only 40-60\% of the hogwash is able to be collected for recycling [7], and the rest is mostly disposed of as rubbish. The main chemical composition of hogwash is the high fatty acid glycosides [8], which are reliable sources of fatty acids and can be used as collectors for mineral flotation. More than 800 thousand tons fatty acid collector are consumed in China's ore flotation ore. The traditional process of preparing fatty acids is mainly through chemical synthesis [9]. As the cost of flotation reagents increases, the use of fatty acids refined from hogwash oil as flotation collectors is increasingly economical and environmentally friendly. Sun et al. [10] refined the mixed fatty acids from hogwash oil, which was used to separate diaspore from

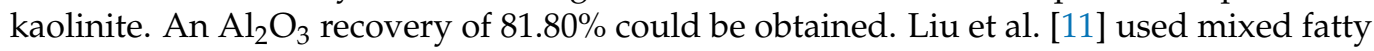


acids refined from hogwash oil as the collector of phosphate ore flotation and they got a concentrate with $\mathrm{P}_{2} \mathrm{O}_{5} 28.46 \%$ and $\mathrm{P}_{2} \mathrm{O}_{5}$ recovery of $87.2 \%$.

The flotation recovery is relatively low, and high pulp temperatures and large quantities are necessary when using the mixed fatty acids refined from hogwash oil as flotation collectors directly $[12,13]$. Studies have attempted to enhance flotation performance of mixed fatty acids by mixing with other surfactants. Xu et al. [14] found that the preparation of $10 \%$ dodecyl trimethyl ammonium chloride in mixed fatty acids could improve its collectability and reduce consumption by approximately $60 \%$ for the flotation of lithium pegmatite ore. Cao et al. [15] found that the recovery of apatite flotation increased by $10 \%$ when fatty acids collector was mixed with $10 \%$ sodium dodecyl sulfonate. Jong et al. [16] confirmed that fatty acids collector mixed with some oleic acid amide exhibited a better collecting capacity on apatite. The mixed fatty acids prepared from hogwash oil contained saturated fatty acids (SFA), such as stearic acid and palmitic acid, and unsaturated fatty acids (UFA), such as oleic acid, linoleic acid, and linolenic acid [10,17-19]. Yu et al. [18] compared the flotation performance of four different mixed fatty acids prepared from hogwash oil which are from different regions in China. They found that mixed fatty acids containing more unsaturated fatty acids could yield better flotation results. Thus, in our study, we attempted to improve the flotation performance of original fatty acids prepared from hogwash oil by separating the original fatty acids into its constituent components to determine what types of fatty acids were responsible for poor flotation performance.

In this work, the mixed fatty acids (MFA) prepared from hogwash oil were separated into SFA and UFA via a chemical method. Gas chromatography-mass spectrometry (GC-MS), FT-IR, iodine value detection and melting point measurements were used to confirm the separation. Quartz flotation tests were used to compare the flotation performance of SFA and UFA. The adsorption properties and mechanisms of SFA and UFA on quartz surface were compared by zeta potential, FT-IR and XPS analysis.

\section{Materials and Methods}

\subsection{Mineral Sample}

Hand-picked pure quartz samples were obtained from Sijiaying Iron Mine, Hebei Province, China. The samples were crushed with a hammer. In addition, then the crushed samples were ground with ceramic ball mill and subsequently wet-sieved to obtain size fractions $-0.150 \mathrm{~mm}$. The chemical compositions of the obtained quartz sample were presented in Table 1. The quartz sample was super pure comprising $99.20 \% \mathrm{SiO}_{2}$.

Table 1. Chemical composition of the single quartz ( $w \mathrm{t} \%$ ).

\begin{tabular}{cccccc}
\hline Sample & $\mathrm{SiO}_{\mathbf{2}}$ & $\mathrm{Al}_{\mathbf{2}} \mathbf{O}_{\mathbf{3}}$ & $\mathbf{K}$ & $\mathbf{S}$ & $\mathrm{CaO}$ \\
\hline Pure quartz & 99.20 & 0.67 & 0.054 & 0.0046 & $<0.001$ \\
\hline
\end{tabular}

\subsection{Reagents}

The hogwash oil was provided by Wuhan Zeyu Waterproof Building Materials, Ltd., (Wuhan, China). Calcium chloride $\left(\mathrm{CaCl}_{2}\right)$ with analytical purity was used as activator in the quartz flotation, which was supplied by Tianjin Kemiou Chemical Reagent Co., Ltd., Tianjin, China. The $0.10 \mathrm{~mol} / \mathrm{L} \mathrm{HCl}$ and $0.10 \mathrm{~mol} / \mathrm{L} \mathrm{NaOH}$ solutions were used to adjust the $\mathrm{pH}$ of the flotation pulp. The MFA, SFA and UFA prepared from hogwash oil were used as flotation collectors for quartz flotation. In particular, all collectors were saponified by $20 \% \mathrm{NaOH}$ solution in a mass ratio of $1: 1$ and diluted to $0.2 \%$ solution before use.

\subsection{FT-IR Analysis}

In the measurement of the FT-IR spectrum (Nicolet 380 FT-IR spectrometer, Thermo Fisher Scientific, Waltham, MA, USA), the spectral pure $\mathrm{KBr}$ and quartz were further ground to $-2 \mu \mathrm{m}$ in an agate mortar. Five grams of the ground quartz was mixed with $50 \mathrm{~mL}$ aqueous solution with $50 \mathrm{mg} / \mathrm{L} \mathrm{CaCl}_{2}$ and then treated with $100 \mathrm{mg} / \mathrm{L}$ collectors 
(UFA or SFA) at $\mathrm{pH} 11.50$, and $25^{\circ} \mathrm{C}$. After being stirred for $0.5 \mathrm{~h}$, the pulp was filtered and then washed with distilled water three times and finally dried in a vacuum oven at $50{ }^{\circ} \mathrm{C}$. Finally, a mixture of the quartz sample and $\mathrm{KBr}$ at a mass ratio of 1:100 was pressed into a thin disk for FT-IR spectroscopy.

\subsection{Flotation Tests}

Micro-flotation tests were conducted using an $\mathrm{XFG}_{\mathrm{II} 50}$ with a 50-mL cell (Changchun Prospecting Machinery Factory, Changchun, China). A $5 \mathrm{~g}$ quartz sample was placed in the cell which are filled with ultra-pure water. A pH regulator $(0.10 \mathrm{~mol} / \mathrm{L} \mathrm{HCl}$ or $\mathrm{NaOH})$, $\mathrm{CaCl}_{2}$ activator, and collector (MFA, SFA or UFA) were sequentially added to the cell. The conditioning time of each reagent was $2 \mathrm{~min}$ at a rotation speed of $1992 \mathrm{rpm}$, and flotation was conducted for $4 \mathrm{~min}$. Finally, the Equation (1) is used to calculate the recoverye, where $a$ and $b$ are the dry weights $(\mathrm{g})$ of froth products and tailings, respectively.

$$
\varepsilon=a /(a+b) \times 100 \%
$$

\subsection{Zeta Potential Measurements}

Before the measurement of zeta potential (Malvern Instruments Nano-ZS90, Malvern Panalytical, Malvern, UK), the quartz sample was further ground to below $0.005 \mathrm{~mm}$ and prepared as a $0.06 \%$ suspension. Zeta potential was measured in the absence or presence of $\mathrm{CaCl}_{2}$ and collectors at $25^{\circ} \mathrm{C}$. After agitating for $10 \mathrm{~min}, 0.10 \mathrm{~mol} / \mathrm{mL} \mathrm{HCl}$ and $\mathrm{NaOH}$ were used to regulate the pulp $\mathrm{pH}$. Each measurement was repeated three times, and the average was adopted.

\subsection{X-Ray Photoelectron Spectroscopy}

XPS analysis of quartz and quartz treated with $\mathrm{CaCl}_{2}$ and collector (UFA or SFA) at $\mathrm{pH}$ 11.50 were measured with an American Thermo VG ESCALAB 250 spectrometer (Thermo Fisher Scientific, Waltham, MA, USA). The X-ray source was monochromatized Al K $\alpha$ $(1486.7 \mathrm{eV})$ with a power of $150 \mathrm{~W}(15,000 \mathrm{~V} \times 10 \mathrm{~mA})$. The pressure in the sample chamber was $5.0 \times 10^{-8} \mathrm{~Pa}$. A value of $284.8 \mathrm{eV}$ was chosen as the standard $\mathrm{C}(1 \mathrm{~s})$ to calibrate the binding energy.

\section{Results and Discussion}

\subsection{Preparation of Collectors}

Hogwash oil was first water washed and treated by $40 \% \mathrm{NaOH}$ solution and $40 \%$ $\mathrm{H}_{2} \mathrm{SO}_{4}$ solution to obtain the mixed fatty acids (MFA). GC-MS was used to identify the main components of the MFA [20] and listed them in Table 2. The MFA is comprised of unsaturated fatty acids (29.6\% oleic acid, 32.1\% linoleic acid and 4.5\% linolenic acid) and saturated fatty acids (7.9\% stearic acid and $24.7 \%$ palmitic acid).

Table 2. Fatty acid composition of MFA.

\begin{tabular}{ccc}
\hline Component & Structure & Content/\% \\
\hline Palmitic acid & $\mathrm{CH}_{3}\left(\mathrm{CH}_{2}\right)_{14} \mathrm{COOH}(\mathrm{C} 16: 0)$ & 24.7 \\
Stearic acid & $\mathrm{CH}_{3}\left(\mathrm{CH}_{2}\right)_{16} \mathrm{COOH}(\mathrm{C} 18: 0)$ & 7.9 \\
Oleic acid & $\mathrm{CH}_{3}\left(\mathrm{CH}_{2}\right)_{7} \mathrm{CH}=\mathrm{CH}\left(\mathrm{CH}_{2}\right)_{7} \mathrm{COOH}(\mathrm{C} 18: 1)$ & 29.6 \\
Linoleic acid & $\mathrm{CH}_{3}\left(\mathrm{CH}_{2}\right)_{4}-\left[\mathrm{CH}=\mathrm{CH}-\mathrm{CH}_{2}\right]_{2}-\left(\mathrm{CH}_{2}\right)_{6} \mathrm{COOH}(\mathrm{C} 18: 2)$ & 32.1 \\
Linolenic acid & $\mathrm{CH}_{3} \mathrm{CH}_{2}-\left[\mathrm{CH}=\mathrm{CH}-\mathrm{CH}_{2}\right]_{3}-\left(\mathrm{CH}_{2}\right)_{6} \mathrm{COOH}(\mathrm{C} 18: 3)$ & 4.5 \\
others & $/$ & 1.2 \\
\hline
\end{tabular}

"/" means no specific structure.

The SFA and UFA collectors were prepared from MFA using urea inclusion method [21-23] as described in Equation (2). As reported in our previous study [24], this separation mechanism was investigated by molecular simulation, and the SFA and UFA were characterized by iodine value, melting point measurement and Fourier transform infrared (FT-IR) spectroscopy. The results indicated that UFA comprised fatty acids containing $-\left(\mathrm{CH}=\mathrm{CH}-\mathrm{CH}_{2}\right)_{\mathrm{n}}$ - with an iodine 
value of 162.9 and a melting point as low as $-17.3^{\circ} \mathrm{C}$, which means that the UFA were easy to disperse and dissolve in flotation pulp at low temperatures. In contrast, no $-\left(\mathrm{CH}=\mathrm{CH}-\mathrm{CH}_{2}\right)_{\mathrm{n}^{-}}$ group was detected in the SFA, and the SFA comprised saturated fatty acids. The iodine value and melting point of the SFA were 49.0 and $38.8^{\circ} \mathrm{C}$, respectively. Thus, a high pulp temperature greater than $38^{\circ} \mathrm{C}$ was necessary to ensure the dissolution and dispersion of SFA, which was consistent with the results of the flotation temperature test (Figure 4).

$$
\mathrm{MFA}+m \mathrm{CO}\left(\mathrm{NH}_{2}\right)_{2} \underset{0{ }^{\circ} \mathrm{C}}{\stackrel{\text { Ethanol }}{\longrightarrow}} \mathrm{SFA}\left[\mathrm{CO}\left(\mathrm{NH}_{2}\right)_{2}\right]_{\mathrm{m}} \downarrow+U F A+\Delta H
$$

\subsection{Flotation Tests}

\subsubsection{Conditional Tests of $\mathrm{pH}$}

Quartz flotation tests were used to compare the flotation performance of SFA, UFA, and MFA. Firstly, quartz was floated at various $\mathrm{pH}$ with collector (MFA, UFA or SFA) concentration of $120 \mathrm{mg} / \mathrm{L}$ and activator $\mathrm{CaCl}_{2}$ concentration of $50 \mathrm{mg} / \mathrm{L}$ at $20{ }^{\circ} \mathrm{C}$, and the results was shown in Figure 1. Pulp pH of quartz flotation is typically greater than 8 , and the optimum $\mathrm{pH}$ is approximately 11.5. As the pulp $\mathrm{pH}$ increased from 8 to 11.5 , quartz recovery by collector UFA, MFA and SFA improved, with maxima of $99.01 \%, 89.45 \%$ and $64.10 \%$, respectively. Additionally, the UFA collector had better collectability than those of SFA and MFA at $\mathrm{pH} 8$ to 12.5 .

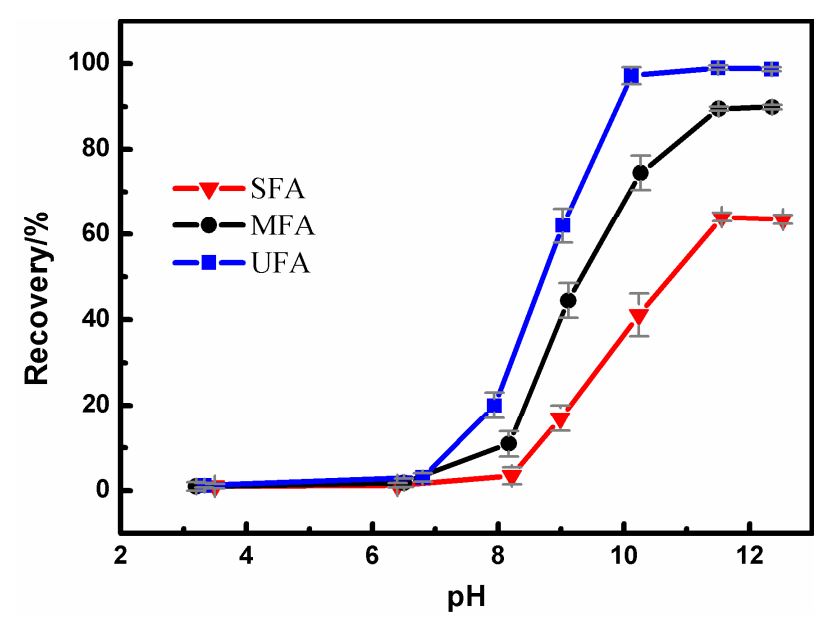

Figure 1. Flotation recoveries of quartz as a function of $\mathrm{pH}$ (collector MFA/UFA/SFA $120 \mathrm{mg} / \mathrm{L}$, activator $\mathrm{CaCl}_{2} 50 \mathrm{mg} / \mathrm{L}$, at $20^{\circ} \mathrm{C}$ ).

\subsubsection{Conditional Tests of Concentration of Collector}

Figure 2 shows the effects of the collector concentration (MFA, SFA and UFA) on quartz flotation at $20{ }^{\circ} \mathrm{C}$ and $\mathrm{pH}$ 11.50. As the UFA concentration of pulp was more than $80 \mathrm{mg} / \mathrm{L}$, the quartz recovery was almost $100 \%$. For SFA, quartz recovery was greatest (approximately 64\%) at concentrations between $100 \mathrm{mg} / \mathrm{L}$ to $120 \mathrm{mg} / \mathrm{L}$, which was comparatively achieved with only $30 \mathrm{mg} / \mathrm{L}$ UFA. For MFA, $89.45 \%$ quartz recovery was obtained at $80 \mathrm{mg} / \mathrm{L}$ with negligible improvement, but at higher concentrations. UFA collector separated from MFA showed better quartz flotation performance. 


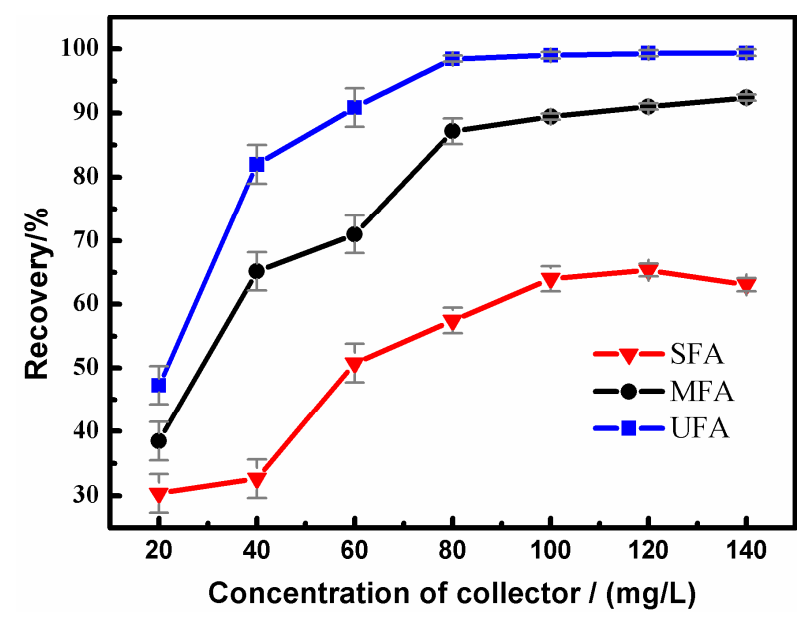

Figure 2. Flotation recoveries of quartz as a function of the concentration of collector MFA, SFA or UFA (activator $\mathrm{CaCl}_{2} 50 \mathrm{mg} / \mathrm{L}$, pulp $\mathrm{pH}=11.5$, at $20^{\circ} \mathrm{C}$ ).

\subsubsection{Conditional Tests of Concentration of $\mathrm{CaCl}_{2}$}

Figure 3 shows the effects of $\mathrm{CaCl}_{2}$ activator on quartz flotation. For the UFA collector, when the concentration of $\mathrm{CaCl}_{2}$ was only $25 \mathrm{mg} / \mathrm{L}$, a high flotation recovery of $99.50 \%$ was obtained. Even at a low $10 \mathrm{mg} / \mathrm{L} \mathrm{CaCl}_{2}$ concentration, quartz recovery by UFA collector remained above $90 \%$, whereas the quartz recoveries were $75 \%$ and $30 \%$ for MFA and SFA respectively. $\mathrm{CaCl}_{2}$ activator concentration should be more than $50 \mathrm{mg} / \mathrm{L}$ for when using MFA and SFA collectors to ensure sufficient activation. The UFA collector required lower $\mathrm{CaCl}_{2}$ concentrations to activate quartz.

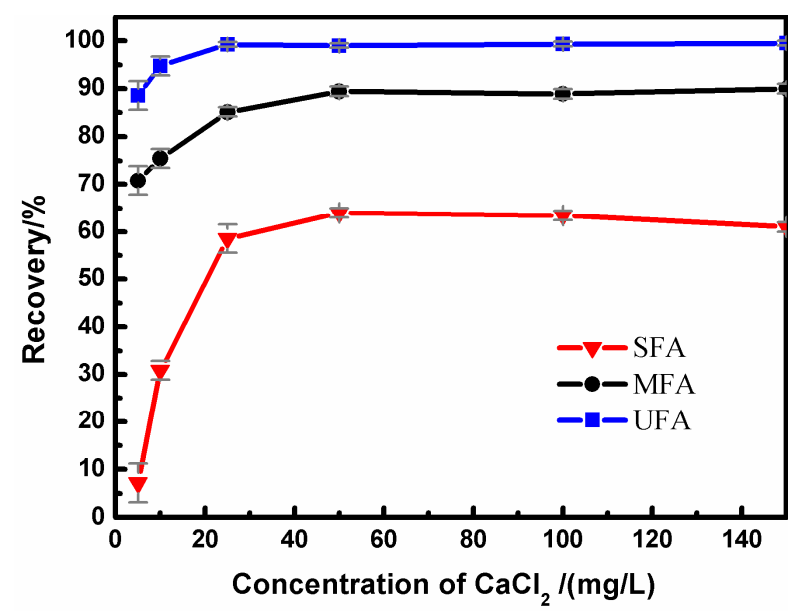

Figure 3. Flotation recoveries of quartz as a function of $\mathrm{CaCl}_{2}$ concentration (collector MFA, SFA or UFA $100 \mathrm{mg} / \mathrm{L}$, pulp $\mathrm{pH}=11.5$, at $20^{\circ} \mathrm{C}$ ).

\subsubsection{Conditional Tests of Temperature}

The flotation properties of collector UFA, MFA and SFA with different pulp temperatures are presented in Figure 4. The UFA collector had excellent adaptability to pulp temperature. Under flotation temperatures between $10{ }^{\circ} \mathrm{C}$ and $50{ }^{\circ} \mathrm{C}$, the recoveries of quartz flotation by UFA were higher than $98 \%$. However, similar quartz recoveries by MFA and SFA flotation required pulp temperatures greater than $30^{\circ} \mathrm{C}$ and $35^{\circ} \mathrm{C}$, respectively. The quartz flotation results demonstrated that the flotation performance of SFA separated from MFA was very unfavorable, whereas UFA was an excellent collector with superior low-temperature adaptability for quartz flotation. 


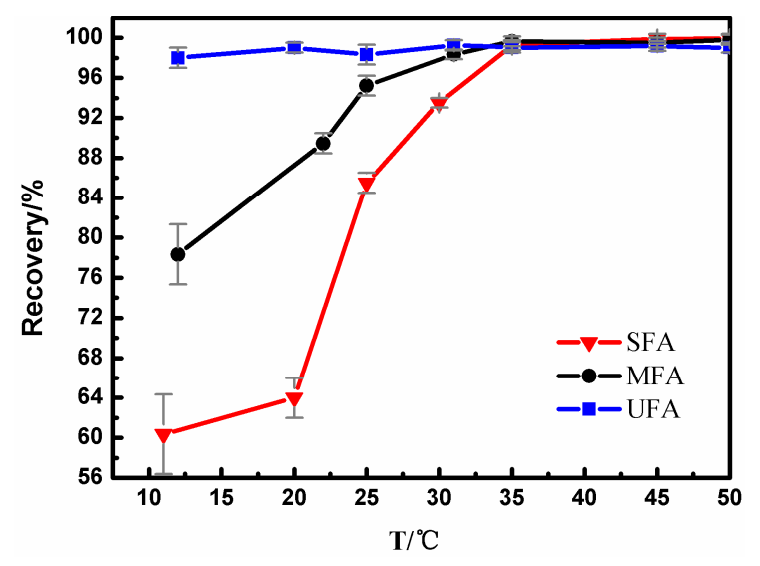

Figure 4. Flotation recoveries of quartz as a function of pulp temperature (collector MFA, SFA or UFA $100 \mathrm{mg} / \mathrm{L}$, activator $\mathrm{CaCl}_{2} 50 \mathrm{mg} / \mathrm{L}$ and pulp $\left.\mathrm{pH}=11.5\right)$.

\subsection{Zeta Potential Analyses}

Zeta potential analyses were used to investigate the differences in electrostatic interactions between quartz and the two separate components (SFA and UFA) from MFA. The zeta potential measurements of pure at various $\mathrm{pH}$ values are shown in Figure 5. The zeta potential of quartz surface was negative within a pulp $\mathrm{pH}$ range from 2 to 14; and as the $\mathrm{pH}$ value increased, the zeta potential continued to decrease. After treated with $50 \mathrm{mg} / \mathrm{L} \mathrm{CaCl}_{2}$ (Figure 5), the zeta potential significantly increased compared with Figure 5. This was due to the adsorption of calcium ions on the negative quartz surface, and the electrostatic force in the adsorption process. The $\mathrm{CaCl}_{2}$ activated quartz surface remained negative throughout the studied $\mathrm{pH}$ range.

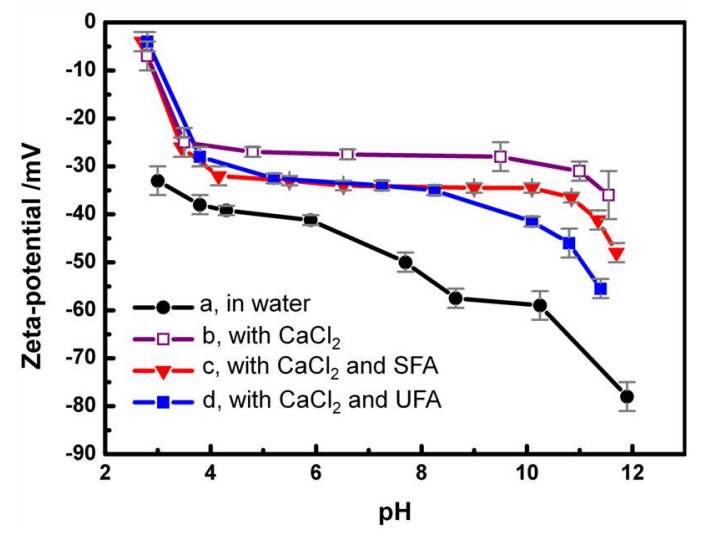

Figure 5. Zeta potentials of quartz as a function of $\mathrm{pH}$ in the absence (a), presence of $50 \mathrm{mg} / \mathrm{L}$ activator $\mathrm{CaCl}_{2}$ (b), $50 \mathrm{mg} / \mathrm{L}$ activator $\mathrm{CaCl}_{2}$ and $100 \mathrm{mg} / \mathrm{L}$ collector SFA (c), or $50 \mathrm{mg} / \mathrm{L}$ activator $\mathrm{CaCl}_{2}$ and $100 \mathrm{mg} / \mathrm{L}$ collector UFA (d).

Figure 5 respectively show the changes in zeta potential when the SFA or UFA collectors was added at $100 \mathrm{mg} / \mathrm{L}$ to $50 \mathrm{mg} / \mathrm{L}$ activator $\mathrm{CaCl}_{2}$ activated quartz system. The SFA and UFA collectors significantly reduced the negative zeta potential of activated quartz when the pulp $\mathrm{pH}$ was above 5 , which was reflected in the flotation results of the $\mathrm{pH}$ test (Figure 1). To reveal the effects of SFA and UFA on the surface potential of activated quartz, the $100 \mathrm{mg} / \mathrm{L}$ SFA and UFA were analyzed. Based the compositions of fatty acids shown in Table 2, palmitic acid (C16:0) and linoleic acid (C18:2) were selected to represent the parameters of SFA and UFA respectively. The solution equilibria of SFA and UFA were as follows. (3) to (6) [25].

Where $S, k_{1}, k_{2}$ and $k_{3}$ are dissolution, acid dissociation, ions association and ionmolecular complexation constants, respectively having values of $S=1.6 \times 10^{-5} \mathrm{~mol} / \mathrm{L}$, 
$k_{1}=10^{-10.0}, k_{2}=10^{4.0}, k_{3}=10^{4.7}$ for SFA and $S=5.7 \times 10^{-6} \mathrm{~mol} / \mathrm{L}, k_{1}=10^{-9.0}, k_{2}=10^{4.5}$, $k_{3}=10^{5.2}$ for UFA [25-27]. The $\log c-p H$ diagrams of the SFA and UFA solution were calculated and are shown in Figure 6A,B. UFA primarily existed as fatty acid molecules from $\mathrm{pH} 2$ to 10. Above PH10, fatty acid anions and anion associations were the main compositions. The dissociation pattern of SFA was similar to that of UFA, but the significant change in composition was observed at approximately $\mathrm{pH} 12$. These results were consistent with the results shown in Figure 1, i.e., the suitable $\mathrm{pH}$ values for the SFA and UFA slurries were approximately 10 to 13 and 12 to 13 , respectively. In particular, the concentration of $\mathrm{RCOO}^{-}$anions in the UFA solution at suitable $\mathrm{pH}$ was 1.6 times that for SFA, this accounted for the higher UFA, which was the reason the quartz recovery of UFA was higher. When the pulp $\mathrm{pH}$ was approximately 12, both SFA and UFA were acid dissociated, thereby preventing electrostatic attraction between SFA/UFA anions and the negatively activated quartz surface. It was obvious that there was no electrostatic attraction between SFA/UFA anions and the negative activated quartz surface. The zeta potential decrease observed when activated quartz was treated with SFA or UFA may be due to chemisorption between the collectors and the activated quartz surface.
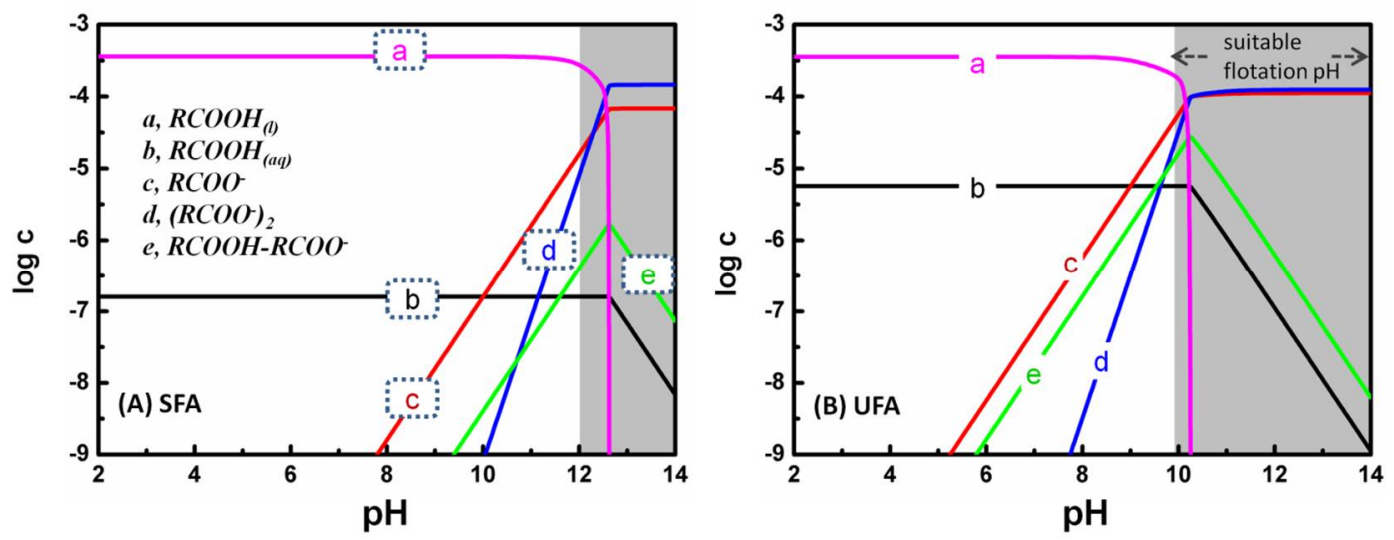

Figure 6. The species distribution diagrams of $100 \mathrm{mg} / \mathrm{L}\left(3.8 \times 10^{-4} \mathrm{~mol} / \mathrm{L}\right) \mathrm{SFA}(\mathrm{A})$ and $100 \mathrm{mg} / \mathrm{L}\left(3.6 \times 10^{-4} \mathrm{~mol} / \mathrm{L}\right)$ UFA (B) solution as a function of $\mathrm{pH}$.

\subsection{FT-IR Analyses}

Figure 7 showed the FT-IR spectra of quartz, the FT-IR spectra of quartz treated with $50 \mathrm{mg} / \mathrm{L} \mathrm{CaCl}_{2}$ and $100 \mathrm{mg} / \mathrm{L}$ UFA and the FT-IR spectra of quartz treated with $50 \mathrm{mg} / \mathrm{L} \mathrm{CaCl}_{2}$ and $100 \mathrm{mg} / \mathrm{L}$ SFA. The vibrations approximately $3128 \mathrm{~cm}^{-1}$ and $1400 \mathrm{~cm}^{-1}$ were caused by $\mathrm{H}_{2} \mathrm{O}$ in air or adsorbed $\mathrm{H}_{2} \mathrm{O}$ on quartz surface [28]. The vibrations near $1089 \mathrm{~cm}^{-1}, 796 \mathrm{~cm}^{-1}$ and $691 \mathrm{~cm}^{-1}$ belonged to the symmetric stretching and bending vibrations of Si-O-Si [29].

After treatment with $\mathrm{CaCl}_{2}$ and collector UFA/SFA, as shown in Figure 7, in both spectra, stretching vibration absorption vibrations of the $-\mathrm{CH}_{3},-\mathrm{CH}_{2}$ and $\mathrm{C}=\mathrm{O}$ groups could be seen at positions near $2928 \mathrm{~cm}^{-1}, 2852 \mathrm{~cm}^{-1}$ and $1793 \mathrm{~cm}^{-1}$, respectively [30,31], suggesting that both the collector UFA and SFA had adsorbed on the activated quartz surface. Additionally, the stretching vibration absorption vibrations of the $\mathrm{C}=\mathrm{O}$ group shifted approximately $84 \mathrm{~cm}^{-1}$ compared to those of pure UFA and SFA $\left(1709 \mathrm{~cm}^{-1}\right)$, indicating that $\mathrm{C}=\mathrm{O}$ group strengthened and chemisorption occurred [24]. The vibrations located at $3420 \mathrm{~cm}^{-1}$ (both in Figure 7) illustrated the presence of hydrogen bond adsorption [29]. Thus, FT-IR revealed that both UFA and SFA could be adsorbed onto the activated quartz surface by chemical and hydrogen bonding adsorption. 


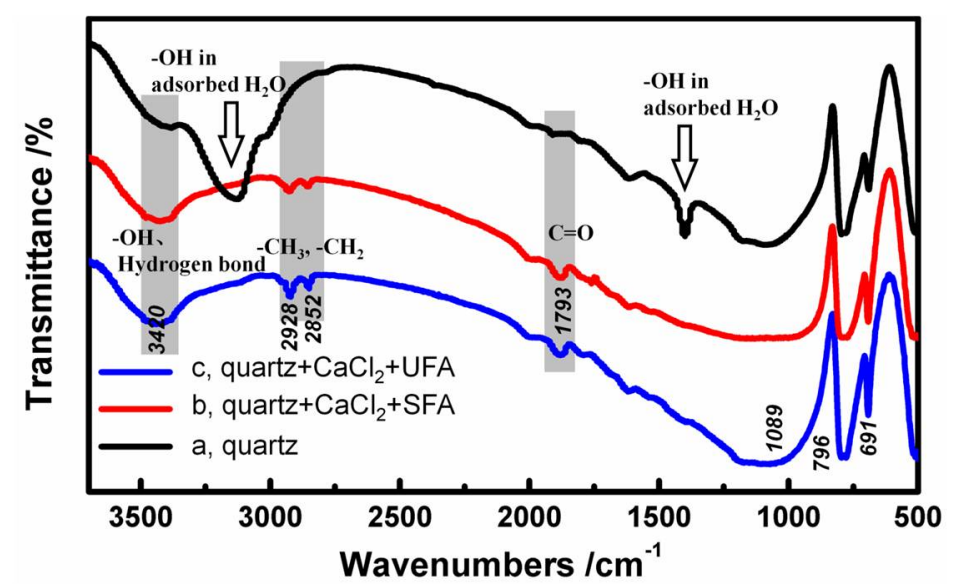

Figure 7. FT-IR spectra of pure quartz (a), quartz treated with $50 \mathrm{mg} / \mathrm{L} \mathrm{CaCl}_{2}$ and $100 \mathrm{mg} / \mathrm{L} \mathrm{SFA} \mathrm{(b),}$ and quartz treated with $50 \mathrm{mg} / \mathrm{L} \mathrm{CaCl}_{2}$ and $100 \mathrm{mg} / \mathrm{L} \mathrm{UFA} \mathrm{(c).}$

\subsection{XPS Analysis}

Figure 8 showed the XPS analysis of pure quartz, the XPS analysis of quartz treated with $50 \mathrm{mg} / \mathrm{L} \mathrm{CaCl}_{2}$ and $100 \mathrm{mg} / \mathrm{L}$ UFA at $\mathrm{pH} 11.50$, and $25^{\circ} \mathrm{C}$ and the XPS analysis of quartz treated with $50 \mathrm{mg} / \mathrm{L} \mathrm{CaCl}_{2}$ and $100 \mathrm{mg} / \mathrm{L} \mathrm{SFA}$ at $\mathrm{pH} 11.50$, and $25^{\circ} \mathrm{C}$. The results were summarized in Table 3. In the XPS spectra of quartz (Figure 8), an extremely weak $\mathrm{C}(1 \mathrm{~s})$ vibration at $284.8 \mathrm{eV}$ was due to $\mathrm{C}-\mathrm{C}$ and $\mathrm{C}-\mathrm{H}$ bonds of hydrocarbon contamination from the environment [32]. In addition, the vibrations around $532 \mathrm{eV}, 153 \mathrm{eV}$ and $103 \mathrm{eV}$ were related to the presence of oxygen and silicon [29] There was no other obvious vibrations, which indicated that the quartz was relatively pure and clear.

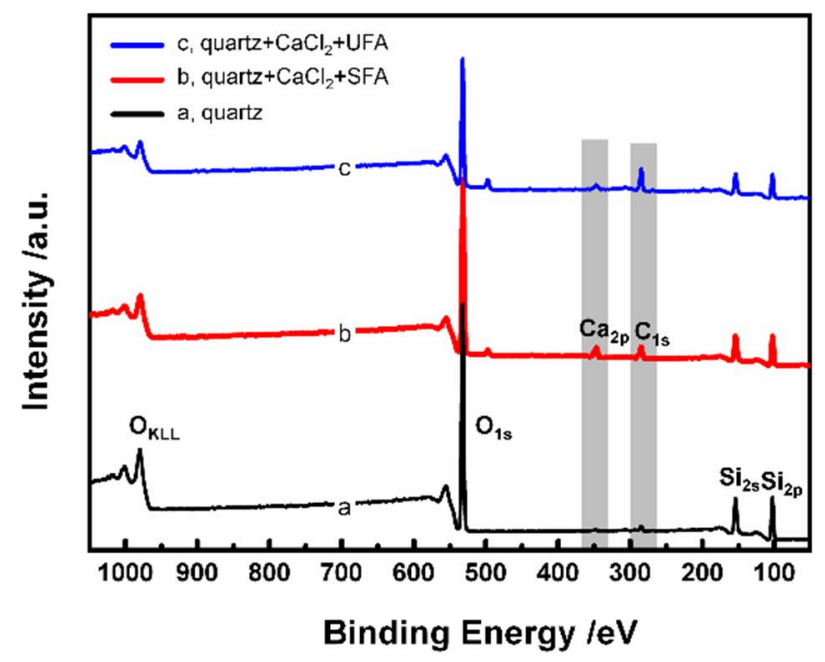

Figure 8. XPS survey spectrum of pure quartz (a), quartz treated with $50 \mathrm{mg} / \mathrm{L} \mathrm{CaCl}_{2}$ and $100 \mathrm{mg} / \mathrm{L}$ SFA (b), and quartz treated with $50 \mathrm{mg} / \mathrm{L} \mathrm{CaCl}_{2}$ and $100 \mathrm{mg} / \mathrm{L} \mathrm{UFA} \mathrm{(c).}$

Table 3. XPS characterization of reference compounds.

\begin{tabular}{ccccc}
\hline \multirow{2}{*}{ Sample } & \multicolumn{4}{c}{ Element at.\% (BE, eV) } \\
\cline { 2 - 5 } & $\mathbf{C}$ & $\mathbf{O}$ & $\mathbf{S i}$ & $\mathbf{C a}$ \\
\hline Quartz & $5.1(284.8)$ & $64.0(532.4)$ & $31.0(102.9)$ & \\
Quartz $+\mathrm{CaCl}_{2}+\mathrm{SFA}$ & $13.8(284.7)$ & $58.4(532.3)$ & $25.5(102.9)$ & $2.3(346.5)$ \\
Quartz $+\mathrm{CaCl}_{2}+$ UFA & $23.1(284.7)$ & $51.1(532.3)$ & $24.2(102.9)$ & $0.3(346.8)$ \\
\hline
\end{tabular}

After treatment with $\mathrm{CaCl}_{2}$ and SFA (Figure 8), Ca adsorption (Ca 2 $\mathrm{p}_{3 / 2}$ at $346.5 \mathrm{eV}$, concentration of 2.3 at.\%) was observed on the quartz surface. Furthermore, $\mathrm{O}(1 \mathrm{~s})$ and 
$\mathrm{Si}(2 \mathrm{p})$ contents decreased by 5.6 at. $\%$ and 5.5 at.\%, respectively, whereas the contents of $\mathrm{C}(1 \mathrm{~s})$ increased by $8.8 \%$, compared with that of the initial quartz surface. Similar XPS results were observed for quartz treated with $\mathrm{CaCl}_{2}$ UFA (Figure 8) wherein a new $\mathrm{Ca}$ vibration ( $\mathrm{Ca} 2 \mathrm{p}_{3 / 2}$ at $346.8 \mathrm{eV}$ concentration of 0.4 at.\%) appeared and the contents of $\mathrm{O}(1 \mathrm{~s}), \mathrm{Si}(2 \mathrm{p})$ and $\mathrm{C}(1 \mathrm{~s})$ changed significantly. However, the contents of $\mathrm{O}(1 \mathrm{~s}), \mathrm{Si}(2 \mathrm{p})$ and $\mathrm{Ca}(2 \mathrm{p})$ were 7.3 at. $\%, 1.3$ at. $\%$ and 1.9 at.\% lower, respectively, and the $\mathrm{C}(1 \mathrm{~s})$ content was 9.3 at.\% higher, compared with the activated quartz surface treated by SFA. Namely more UFA molecules were adsorbed and covered the $\mathrm{O}, \mathrm{Si}$ and $\mathrm{Ca}$ atoms on the activated quartz surface. These results revealed that both SFA and UFA could adsorb onto quartz surfaces activated by calcium ions, but the adsorption of UFA was much stronger.

To further compare the adsorption of SFA and UFA on quartz, the curve fitting of $C(1 s)$ vibrations of different samples are shown in Figure 9A-C. Figure 9A shows that the $\mathrm{C}(1 \mathrm{~s})$ vibration of the pure quartz surface was the only component at $284.8 \mathrm{eV}$ assigned to the $\mathrm{C}(1 \mathrm{~s})$ of $\mathrm{C}-\mathrm{C}$ and $\mathrm{C}-\mathrm{H}$ bonds from the hydrocarbon contamination. Figure $9 \mathrm{~B}, \mathrm{C}$ show that the activated quartz surface treated with SFA and UFA included three components at approximately $284.8 \mathrm{eV}, 286.6 \mathrm{eV}$ and $288.9 \mathrm{eV}$ due to the $\mathrm{C}(1 \mathrm{~s})$ bonds from $\mathrm{C}-\mathrm{C} / \mathrm{C}-\mathrm{H}$ bonds, $\mathrm{O}=\mathrm{C}-\mathrm{OH}$ bonds and $\mathrm{O}=\mathrm{C}-\mathrm{O}^{-}$bonds, respectively $[29,32]$. Obviously, both SFA and UFA had been adsorbed onto the surface of activated quartz. However, the adsorption of UFA was much stronger and more favorable, because the $\mathrm{C}(1 \mathrm{~s})$ content in $\mathrm{C}-\mathrm{C} / \mathrm{C}-\mathrm{H}$ bonds from the sample treated by UFA was significantly higher and the binding energy of the $\mathrm{C}(1 \mathrm{~s})$ vibration of component $\mathrm{O}=\mathrm{C}_{-} \mathrm{O}^{-}$for the sample treated by UFA was $0.4 \mathrm{eV}$ lower, than that of the sample treated by SFA. In addition, the components of $\mathrm{O}=\mathrm{C}-\mathrm{OH}$ bonds were found in both samples treated with SFA and UFA and their binding energies of were almost same. This indicated that the adsorptions of both SFA and UFA may involve hydrogen bonding, which confirmed the results of the FT-IR analysis.

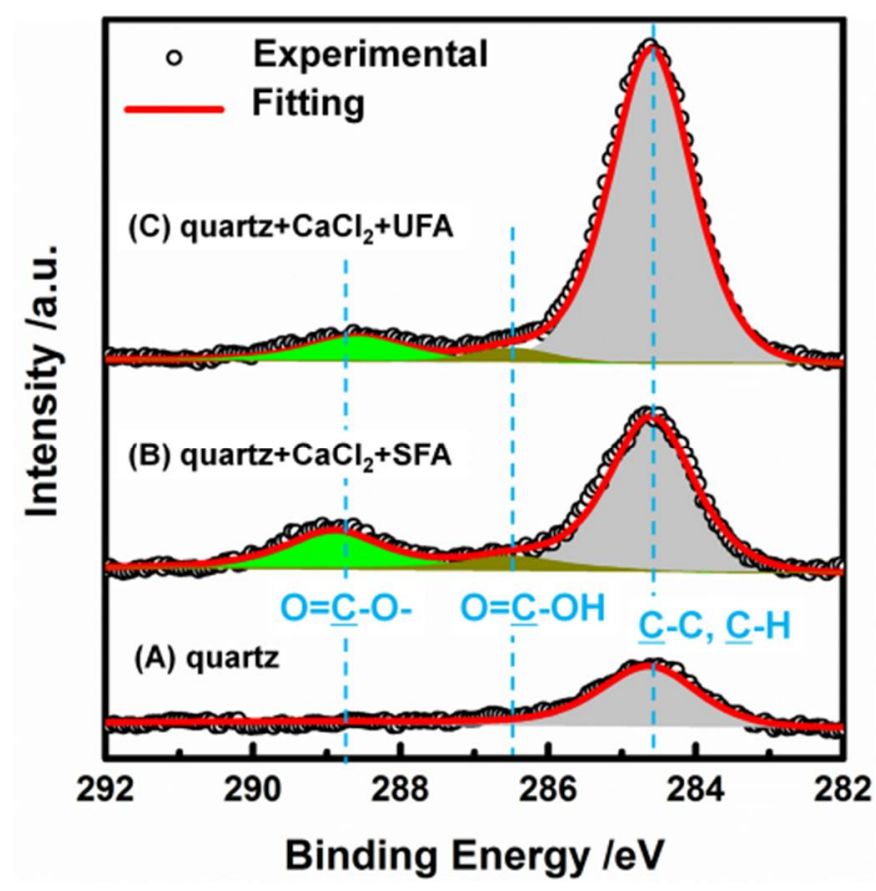

Figure 9. XPS C(1s) spectra of quartz (A), quartz treated with $50 \mathrm{mg} / \mathrm{L} \mathrm{CaCl}_{2}$ and $100 \mathrm{mg} / \mathrm{L} \mathrm{SFA} \mathrm{(B),}$ and quartz treated with $50 \mathrm{mg} / \mathrm{L} \mathrm{CaCl}_{2}$ and $100 \mathrm{mg} / \mathrm{L} \mathrm{UFA} \mathrm{(C).}$

By combining the analyses of flotation test, FT-IR, XPS, and zeta potential measurements, it is evident that the adsorption mechanisms of UFA and SFA on quartz surface are the same as summarized in Figure 10. Both UFA and SFA can adsorb onto quartz surfaces activated by $\mathrm{Ca}^{2+}$ via chemical and hydrogen bonding adsorption. UFA is an extremely excellent collector for quartz even at low flotation temperatures. Comparably, the SFA had 
poor flotation performance requiring y high flotation temperatures and pulp $\mathrm{pH}$ to ensure dissolution and dispersion.

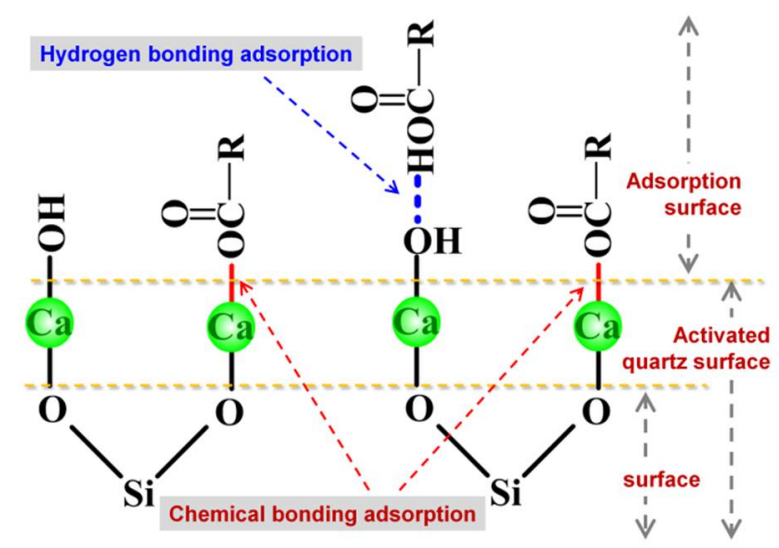

Figure 10. The schematic view on the adsorption mechanism of UFA and SFA on quartz surface.

\section{Conclusions}

Mixed fatty acids (MFA) prepared from hogwash oil consisted of $7.9 \%$ stearic acid, $24.7 \%$ palmitic acid, $29.6 \%$ oleic acid, $32.1 \%$ linoleic acid, and $4.5 \%$ linolenic acid. MFA can be separated into saturated fatty acids (SFA) and unsaturated fatty acids (UFA) through chemical methods. The quartz flotation results demonstrated that the flotation performance of SFA separated from MFA was very unfavorable, whereas UFA, showed strong collectability and superior low-temperature adaptability for quartz flotation. At $20{ }^{\circ} \mathrm{C}$ and $\mathrm{pH} 11.50$, the highest quartz recoveries of by UFA, MFA and SFA at were $99.01 \%, 89.45 \%$ and $64.10 \%$, respectively. Finally, the zeta potential, FT-IR, and XPS analyses revealed the adsorption mechanism by which both UFA and SFA could be adsorbed onto activated quartz surfaces via chemical and hydrogen bonding, but the adsorption of UFA was much stronger and more favorable. Thus, the unfavorable flotation performance of MFA was due to large amounts of SFA.

Author Contributions: W.G. and Y.Z. conceived and designed the experiments; Y.C. and Y.S. performed the experiments; Y.L. and Y.S. analyzed the data; Y.S. contributed reagents/materials/analysis tools; Y.C. and W.G. wrote the paper. All authors have read and agreed to the published version of the manuscript.

Funding: The authors gratefully acknowledge and appreciate the financial support provided by the National Natural Science Foundation of China (Grant Nos. 51474055 and 51974067).

Institutional Review Board Statement: Not applicable.

Informed Consent Statement: Not applicable.

Conflicts of Interest: The founding sponsors had no role in the design of the study; in the collection, analyses, or interpretation of data; in the writing of the manuscript, and in the decision to publish the results.

\section{References}

1. Duarte, A.C.P.; Grano, S.R. Mechanism for the recovery of silicate gangue minerals in the flotation of ultrafine sphalerite. Miner. Eng. 2007, 20, 766-775. [CrossRef]

2. Filippov, L.O.; Filippova, I.V.; Severov, V.V. The use of collectors mixture in the reverse cationic flotation of magnetite ore: The role of Fe-bearing silicates. Miner. Eng. 2010, 23, 91-98. [CrossRef]

3. Nakhaei, F.; Irannajad, M. Reagents types in flotation of iron oxide minerals: A review. Miner. Process. Extr. Metall. Rev. 2018, 39, 89-124. [CrossRef]

4. Li, Z.Y. Application of RA-915 collector in Lilou concentrator. Met. Mine 2009, 11, 241-243.

5. Lin, X.H.; Lu, P.; Chen, R.H.; Chen, J.; Ma, X.; Lin, B. Preparation and application of a new type of efficient collector RA-315. Min. Metall. Eng. 1993, 13, 31-35. (In Chinese) 
6. Liang, S.; Liu, Z.; Xu, M.; Zhang, T. Waste oil derived biofuels in China bring brightness for global GHG mitigation. Bioresour. Technol. 2012, 131, 139-145. [CrossRef] [PubMed]

7. Lu, F.; Wu, X. China food safety hits the "gutter". Food Control 2014, 41, 134-138. [CrossRef]

8. Tugrul Albayrak, A.; Yasar, M.; Gurkaynak, M.A.; Gurgey, I. Investigation of the effects of fatty acids on the compressive strength of the concrete and the grindability of the cement. Cem. Concr. Res. 2005, 35, 400-404. [CrossRef]

9. Kou, J.; Tao, D.; Xu, G. Fatty acid collectors for phosphate flotation and their adsorption behavior using QCM-D. Int. J. Miner. Process. 2010, 95, 1-9. [CrossRef]

10. Sun, W.; Ouyang, K.; Zhang, L.; Hu, Y.; Chen, C. Preparation of hydrolyzate of hogwash oil (HHO) and its application in separating diaspore from kaolinite. Miner. Eng. 2010, 23, 670-675. [CrossRef]

11. Liu, X.; Li, C.; Luo, H.; Cheng, R.; Liu, F. Selective reverse flotation of apatite from dolomite in collophanite ore using saponified gutter oil fatty acid as a collector. Int. J. Miner. Process. 2017, 165, 20-27. [CrossRef]

12. Quast, K. Flotation of hematite using C6-C18 saturated fatty acids. Miner. Eng. 2006, 19, 582-597. [CrossRef]

13. Yi, Q.; Li, W.; Zhang, X.; Feng, J.; Zhang, J.; Wu, J. Tech-economic evaluation of waste cooking oil to bio-flotation agent technology in the coal flotation industry. J. Clean. Prod. 2015, 95, 131-141. [CrossRef]

14. Xu, L.; Hu, Y.; Tian, J.; Wu, H.; Yang, Y.; Zeng, X.; Wang, Z.; Wang, J. Selective flotation separation of spodumene from feldspar using new mixed anionic/cationic collectors. Miner. Eng. 2016, 89, 84-92. [CrossRef]

15. Cao, Q.; Cheng, J.; Wen, S.; Li, C.; Liu, J. Synergistic effect of dodecyl sulfonate on apatite flotation with fatty acid collector. Sep. Sci. Technol. 2016, 51, 1389-1396. [CrossRef]

16. Jong, K.; Han, Y.; Ryom, S. Flotation mechanism of oleic acid amide on apatite. Colloids Surf. A Physicochem. Eng. Asp. 2017, 523, 127-131. [CrossRef]

17. Satyanarayana, P.A.; Kanth Oleti, R.; Uppalapati, S.; Sridevi, V. A comparative study on characterization of used cooking oil and mustard oil for biodiesel production: Engine performance. Mater. Today Proc. 2018, 5, 18187-18201. [CrossRef]

18. Yu, H.; Wang, H.; Sun, C. Comparative studies on phosphate ore flotation collectors prepared by hogwash oil from different regions. Int. J. Min. Sci. Technol. 2018, 28, 453-459. [CrossRef]

19. Awogbemi, O.; Onuh, E.I.; Inambao, F.L. Comparative study of properties and fatty acid composition of some neat vegetable oils and waste cooking oils. Int. J. Low-Carbon Technol. 2019, 14, 417-425. [CrossRef]

20. Abidin, S.Z.; Patel, D.; Saha, B. Quantitative analysis of fatty acids composition in the used cooking oil (UCO) by gas chromatography-mass spectrometry (GC-MS). Can. J. Chem. Eng. 2013, 91, 1896-1903. [CrossRef]

21. Ilott, A.J.; Palucha, S.; Batsanov, A.S.; Harris, K.D.M.; Hodgkinson, P.; Wilson, M.R. Structural properties of carboxylic acid dimers confined within the urea tunnel structure: An md simulation study. J. Phys. Chem. B 2011, 115, 2791-2800. [CrossRef]

22. Hayes, D.G.; Van Alstine, J.M.; Setterwall, F. Urea-based fractionation of seed oil samples containing fatty acids and acylglycerols of polyunsaturated and hydroxy fatty acids. J. Am. Oil Chem. Soc. 2000, 77, 207-213. [CrossRef]

23. Wu, M.; Ding, H.; Wang, S.; Xu, S. Optimizing Conditions for the Purification of Linoleic Acid from Sunflower Oil by Urea Complex Fractionation. J. Am. Oil Chem. Soc. 2008, 85, 677. [CrossRef]

24. Guo, W.; Zhu, Y.; Han, Y.; Wei, Y.; Luo, B. Separation mechanism of fatty acids from waste cooking oil and its flotation performance in iron ore desiliconization. Minerals 2017, 7, 244. [CrossRef]

25. Somasundaran, P.; Wang, D. Solution Chemistry: Minerals and Reagents; Elsevier Science: Amsterdam, The Netherlands, 2006.

26. Rahman, M.A.; Ghosh, A.K.; Bose, R.N. Dissociation constants of long chain fatty acids in methanol-water and ethanol-water mixtures. J. Chem. Technol. Biotechnol. 1979, 29, 158-162. [CrossRef]

27. Kanicky, J.R.; Shah, D.O. Effect of degree, type, and position of unsaturation on the pKa of long-chain fatty acids. J. Colloid Interface Sci. 2002, 256, 201-207. [CrossRef] [PubMed]

28. Zhou, Y.; He, C.; Yang, X. Water contents and deformation mechanism in ductile shear zone of middle crust along the Red River fault in southwestern China. Sci. China Ser. D Earth Sci. 2008, 51, 1411. [CrossRef]

29. Zhu, Y.; Luo, B.; Sun, C.; Li, Y.; Han, Y. Influence of bromine modification on collecting property of lauric acid. Miner. Eng. 2015, 79, 24-30. [CrossRef]

30. Sahoo, H.; Rath, S.S.; Rao, D.S.; Mishra, B.K.; Das, B. Role of silica and alumina content in the flotation of iron ores. Int. J. Miner. Process. 2016, 148, 83-91. [CrossRef]

31. Han, H.; Hu, Y.; Sun, W.; Li, X.; Cao, C.; Liu, R.; Yue, T.; Meng, X.; Guo, Y.; Wang, J.; et al. Fatty acid flotation versus BHA flotation of tungsten minerals and their performance in flotation practice. Int. J. Miner. Process. 2017, 159, 22-29. [CrossRef]

32. Wang, J.; He, Y.; Li, H.; Yu, J.; Xie, W.; Wei, H. The molecular structure of Inner Mongolia lignite utilizing XRD, solid state 13C NMR, HRTEM and XPS techniques. Fuel 2017, 203, 764-773. [CrossRef] 